\title{
EXPLORING THE ROLE OF INFORMAL LEARNING IN REAL-LIFE LEARNING
}

\author{
Mike Kendall \\ East Midlands Broadband Consortium, Northampton, UK \\ mkendall@embc.org.uk
}

\begin{abstract}
When we refer to real-life learning we can readily image learning taking place in our everyday lives, at work, rest and play, with and without information and communications technology (ICT). The new competencies of young and old peoples to create their own learning communities, using ICT, is one that can provide powerful informal learning situations. The paper will ask questions about the impact of informal learning on attitudes to learning; about the demands placed upon real-life learning provided in professional and vocational education; and upon the role of ICT in building capacity for communities and economies.
\end{abstract}

Key words: Informal learning, learning communities, citizens, social impact, competencies.

\section{INTRODUCTION}

This paper takes the position that real-life learning and lifelong learning are, in effect, the same activity with different names. However, the author acknowledges that it can also be defined with an emphasis on vocational and professional education. Hence, the paper will explore the increasing prominence of lifelong learning, its relationship to community based and informal learning styles as well as its role in vocational and professional education.

Lifelong learning, and hence real-life learning, is a prominent public policy theme for many countries and non-governmental organisations for 
education, economic, political, social and cultural purposes. The increasing prominence of lifelong learning has taken place alongside the increasingly dominant role that ICT has in all public policy considerations. With this is mind IFIP TC3 established the Lifelong Learning Taskforce in 2001 to consider the role of ICT in lifelong learning. The taskforce was responsible for the development of an IFIP TC3 Position Paper on Lifelong Learning (Kendall, et al, 2004) initially published in 2002 and revised in 2004. At the IFIP TC3 e-Train conference in Pori, Finland, 2003, invited participants contributed to the further development of the IFIP TC3 position paper and the subsequent book, Lifelong Learning in the Digital Age: sustainable learning for all in a changing world. (Weert and Kendall, 2004). In this book Kendall (2004) argues that community based learning provides a key interface for the learner and society between informal and formal learning, between learning directed from within and learning directed by others.

\section{THE QUEST FOR LEARNING}

People are natural learners; they seek to explore the world in which they live and work, in which they become social and economic beings. Learning from the cradle whereby a child learns to survive, nurtured by the mother and the immediate family, and as they grow older involves more people and contexts. The informal learning of survival becomes more formal as the child and the family meets the formal educational demands of society. The quest for learning that was initially driven by internal survival instincts becomes formalised and defined by the society in which they are living. This is real-life learning, providing learning for life. The concept of lifelong learning has evolved slowly with the changing requirements of employment and the need for employees to increasingly acquire new competences within the same or new employment. The early definitions of lifelong learning tended to focus on giving adults access to formal courses, generally at educational institutions. Lifelong learning is now a major political issue, one that is being tackled by all governments in the developing and developed world, although not always for the same reasons. The quest for definition often seeks to differentiate the definitions of learning from lifelong or reallife, to draw out new and refined definitions of learning as well as the changing purposes of learning as one progresses through life - it may be learning from the cradle to the grave, but the impact and intent of such learning may not be constant.

In seeking to define the purposes and processes of learning, the Delors Commission (UNESCO, 1996) proposed the four pillars for learning, applicable across nations, in different and evolving social, economic and 
technological contexts. They are: learn to know, learn to do, learn to live together, and learn to be. The French Commission for UNESCO and the Council for Europe, in responding to the Delors Commission, focussed on The Winds of Change in the Teaching Profession (UNESCO 2002) in 2001 recognising that "teaching is changing and becoming more complex, this profession is becoming more diversified." Noting that, "Teaching doesn't only take place in classes or in institutions, but in a larger and more complex system. Teachers no longer simply teach a group of students in a class but do so in a system: an education system, a country, a society and an international education system which makes the teachers of the world." Whilst this relates to the teaching profession, it can readily be applied to the whole of education and training. Real-life learning is no longer simple, if it ever was, it is no longer about simple inputs and outputs defined in narrow competences or closed processes, the demands of the modern world mean that educators are operating in a complex, often global system, with new professions emerging that support the real-life learning of people as citizens, as students, and as employees throughout their lives where change is taking place at an accelerating rate.

The changing purposes and processes for education are evidenced across the globe. In Latin America:

"Education has become increasingly important within governmental policy, and particularly social policy... We need to imagine the building of an education system that is flexible, open to all, independent of age or life conditions: a system that guarantees education as a right for life... We need to think of an open system that incorporates all educational resources in the society, including the media and new communication technologies." (Machado, 2000)

The need to redefine learning to take account of the "...scale of current economic and social change, the rapid transition to a knowledge-based society and demographic pressures resulting from an ageing population in the industrialised countries are all challenges which demand political attention and a new approach to education and training" lead to the Feira European Council to A Memorandum of Lifelong Learning (European Commission 2000). The memorandum defines Lifelong Learning as “...all learning activity undertaken throughout life, with the aim of improving knowledge, skills and competence, within a personal, civic, social and/or employment-related perspective." The challenge is to support and extend learning activity, making it relevant to the social and economic well-being of citizens and employees, seeking to extend access and opportunity through ICT. 


\section{THE QUEST TO EXTEND ACCESS TO LEARNING}

The way people engage with real-life learning is changing as a result of their experience and opportunity to exploit information and communication technologies in an ever growing range of contexts, socially and informally, as well as professionally and formally. For example, Veen (2002) suggests we have a media generation, the 'Homo Zappiens', with new competencies for multi-dimensional scanning, multi-tasking and existing in virtual environments, where school is a meeting place, not a learning place. The public policy drive for lifelong learning leads to a range of considerations. In considering the role of the school, Carnoy (2001) comments that "... the central organising point in our society at the neighbourhood level is the school - elementary and secondary, as well as child development centres. Children could thus act as the fulcrum around which family, community, and the future worker (the child) are brought together in a system of interaction, blending instrumental goals (child-care, development and education) with expressive, emotional, and social interactions". With a strengthened community based role that extends beyond what is often seen as the traditional role of the school, the school is no longer isolated, but "Through the school, other social networks organised at the municipal level could come into contact with each other [and] the development of electronic communications also offers the possibility of creating virtual communities, in a new form of spatial organisation ...".

To extend the range of opportunities to access ICT, the UK government has connected all libraries to broadband networks, with free computers and internet access, supported by newly trained librarians and community tutors. The provision of support to people to develop new competencies and opportunities to use ICT for formal and informal learning, supporting people and their communities to utilise new media, complementing existing roles of the libraries in the provision of services through traditional media, has been a clear public policy goal. Additionally, the UK government has sponsored a programme to provide 7,000 UK online centres across the country in a wide variety of community settings, generally in communities that would not have access to ICT and other online services, such that no citizen is more than one mile from online access in an urban area. The centres' role is to "bridge the gap between those in society who have access to and are able to use information and communications technologies competently, and those who do not. The key success criteria are the extent to which the centres increase ICT awareness, ICT skills and people's participation in local communities." (DfES 2002) The DfES report sought to evaluate the impact of the online centres on informal learners and their subsequent progression into formal learning or into work. The reported findings indicate that $21 \%$ of the users 
surveyed felt that the centre could help them get a job and that $31 \%$ felt it would help them to progress into further or higher education.

In identifying such learning communities, often characterised as communities of self and shared interest, it is possible to envisage social, economic, residential, knowledge and educational as well as familial communities, all of which are undergoing change, often as a result of the opportunities offered by new information and communications technology. "Visions of learning have been evolving, and informal learning communities and communities of practice have become important concepts that highlight the fact that learning is no longer happening in classrooms or through formal e-learning mechanisms. The 'Knowledge Economy' implies a far reaching transformation of the learning process" (Tremblay, 2002). The way we visualise learning communities has also changed, as the Archbishop of Canterbury noted in 2000, "Increasingly we are not only citizens of the world but also citizens of the World Wide Web". Hence our experience of learning communities, whether formal, non-formal or informal has changed, hence the spaces and times in which community based learning can take place are also changing. Perhaps one of the advantages of informal learning is that activities are not mapped to a formal learning process or qualifications, and are often motivated by fun, or the sense of achievement that comes from completing a project.

\section{THE QUEST TO FORMALISE INFORMAL LEARNING}

Employers and training organisations are recognising the growth of informal learning which they are witnessing in the workplace and in the personal experiences of their staff. Increasingly employers and training organisations are observing this energy and commitment that staff and students exercise when engaged in informal learning activities. Cross (2002) argues that "Informal learning is effective because it is personal. The individual calls the shots. The learner is responsible. It's real. How different from formal learning, which is imposed by someone else. Workers are pulled into informal learning: formal learning is pushed at them." Cross further argues that that "Most training is built on the pessimistic assumption that trainees are deficient... rather than make what's good better." The capacity within real-life learning to build on the achievements and enthusiasm to improve economic benefits of learning is acting as a counterbalance to prescribed, or as Cross referred to deficit models of training.

The providers of information and communications systems and services are very aware of the changing marketplace for learning, and are seeking to 
develop tools and understanding that can be used formally and informally. For example, Bob Mosher (2004) from Microsoft acknowledges that as the role of the traditional classroom is declining and e-learning becomes more popular that industry needs to "...harness the more informal technologies that our students are utilising." Stating that, "If you ask many advanced learners today, they will tell you they are gravitating toward these more informal learning methods and away from traditional ones. Understanding, tracking, creating and encouraging these informal methods of learning can reach a growing population of students you may currently be ignoring or losing touch with altogether." He further argues that these methods are becoming more popular is due to their immediacy and relevance, as well as a lack time or budget for formal learning. "With the maturation of our learners and the advent of collaboration technologies, informal learning can become a powerful part of a company's robust learning offering." The recognition of a clear business case from the technology industry means that increased levels of investment and promotion of supporting tools will increase. The ready access to the internet, with the ubiquitous use of the browser, means that further tools will be made available and exploited by the formal and informal training communities.

The Campaign for Learning, a UK based lobby group, carried out a survey in Summer 2000 about attitudes to eLearning in the workplace. The survey found that the majority of eLearning occurred in the workplace, with nearly a third of learners doing most of their eLearning at home. The formal eLearning tended to be work related and required by employers, whereas informal eLearning was most frequently surfing the web. The survey found that "The quality of the learning experience is rated more highly for informal learning ( $58 \%$ excellent or good) than for formal methods ( $45 \%)$.

The increased availability of the internet, supported by communities of practice and interest, where self-determined learning goals are developed, implicitly and explicitly in the actions and desires of citizens, the impact of real-life learning is having a broadly based impact. In the UK where local government is promoting increased access to and the use of the internet, "...new types of internet-based community are more visible, and where people have engaged online around local issues, there has been a tendency to by-pass traditional democratic institutions." (NLGN, 2004) A US study suggested that the internet can be a force for local and non-local community, specifically that "The internet helps many people find others who share their interests no matter how distant they are, and it also helps them increase their contact with groups and people they already know and it helps them feel more connected to them." (Horrigan 2002) Suggesting that the internet connects people regardless of the distance. The internet supports people to belong to communities through social software which allows groups of 
people to communicate, and importantly collaborate and begin to develop a collective memory, actions and goals, whether this is through email, chat or more formal web sites such as the BCC's ICAN web site www.bbc.co.uk/ican which supports people to form communities of interest, launch public campaigns, taking the first step in addressing issues that face them. In this context the internet is not just providing information, it is providing social contact, perhaps a different digital divide. As I have argued elsewhere (Kendall, 2000) lifelong, real-life learning requires active participation in learning teams and communities and that citizenship is lifelong learning, and hence real-life learning.

\section{CONCLUSION}

Informal learning has always been a part of real-life learning. Its role is gaining increasing recognition as employers' and governments' seek to mobilise people to exploit ICT to increase economic and social well-being, for all. However, the opportunities to exploit the growing confidence and competence of citizens is not yet being utilised effectively in vocational and professional education; it is not yet changing the premise on which work based training is provided, moving from a deficit model of provision to one building on the achievements and enthusiasm of people.

\section{REFERENCES}

Campaign for Learning (2000), Attitudes to eLearning in the Workplace, London

Carnoy, M. (2001) Work, Society Family and Learning for the Future. In: What Schools for the Future, OECD, Paris

Cross, J. (2003) Informal Learning: A Sound Investment, CLO Magazine October 2003, CLOmedia.com

DfES (2002) Evaluation of Pioneer and Pathfinder UK online centres: follow up study, Hall Aitken Associates, DfES

European Commission (2000) A Memorandum on Lifelong Learning. Brussels, 30.10.2000, $\operatorname{SEC}(2000) 1832$.

Horrigan, J (2002) Online communities: Networks that nurture long distance relationships and local ties, PEW Internet and American Life Project

Kendall, M. (2000) Citizenship is lifelong learning: the challenge of information and communications technology. In: Benzie D. and D. Passey (Eds.), Proceedings of Conference on Educational Uses of ICT, Publishing House of Electronics Industry, Beijing, 2000

Kendall, M (2004A) Community Based Learning: Developing the interface between formal and informal learning communities In: Weert, Tom J. van and Kendall, Mike (Eds.) Lifelong Learning in the Digital Age, Kluwer, Boston 
Kendall, M., Samways, B., Weert, T J van and Wibe, J (2004) IFIP TC3 Position Paper on Lifelong Learning In: Weert, Tom J. van and Kendall, Mike (Eds.) Lifelong Learning in the Digital Age, Kluwer, Boston

Machado, A.L. (2000) Current status and perspectives for education in Latin America In: Taylor, H. and Hogenbirk, P. (Eds.) The Schools of the Future, Kluwer, Boston

Mosher, B. (2004) The Power of Informal Learning, CLO Magazine July 2004, CLOmedia.com

NLGN, 2004, invisible villages: techno-localism and the enabling council, New Local Government Network, London

Tremblay, D.G. (2002) Informal learning communities in the knowledge economy: informal knowledge development in the multimedia sector. In: Passey, D \& M. Kendall (Eds.) TelELEARNING: The Challenge of the Third Millennium. Kluwer, Boston.

UNESCO (1996) Education Holds a Treasure Prepared by Jacques Delors on behalf of the International Commission on Education for the Twenty First Century.

UNESCO (2002) Winds of change in the teaching profession, French National Commission for UNESCO, Paris

Veen, W. (2002) Students of the media generation, Coping with homo zappiens. Voordracht op de SURF Onderwijsdagen 2002, SURF, Utrecht. http://www.surf.n1/ onderwijsdagen $2002 /$ video/veen/index.htm

Weert, Tom J. van and Kendall, Mike (Eds.) (2004) Lifelong Learning in the Digital Age: Sustainable learning for all in a changing world Kluwer Academic Publishers, Boston 